\title{
Buku Ajar Berbasis Problem Based Learning dan Pengaruhnya terhadap Kemampuan Literasi Siswa Kidal Kelas IV SD
}

\author{
Made Agus Dwi Pradnyana Dita ${ }^{*}$, I Wayan Sujana ${ }^{2}$, Ni Wayan Suniasih ${ }^{3}$
}

1,2,3 Program Studi Pendidikan Guru Sekolah Dasar, Universitas Pendidikan Ganesha, Singaraja, Indonesia

\section{ARTICLE IN F O}

Article history:

Received March 09, 202

Revised April 15, 2021

Accepted September 30, 2021

Available online October 25, 2021

Kata Kunci:

Buku Ajar, Literasi Siswa Kidal

Keywords:

Composing, Textbook, LeftHanded



This is an open access article under the CC BY-SA license.

Copyright (C) 2021 by Author. Published by Universitas Pendidikan Ganesha

\begin{abstract}
A B S T R A K
Belum adanya buku ajar sesuai dengan karakteristik anak kidal. Pada saat anak kidal menggunakan buku konvensional, anak kidal merasa kurang nyaman dalam membuka buku konvensional menggunakan tangan kirinya. Penelitian ini bertujuan untuk menciptakan buku ajar berbasis Problem Based Learning dan pengaruhnya terhadap kemampuan literasi siswa kidal kelas IV $\mathrm{SD}$. Jenis penelitian merupaka penelitian pengembangan menggunakan model Hannafin and Peck yang terdiri dari tiga tahapan yaitu tahap penilaian kebutuhan/analisis kebutuhan, tahap desain, serta tahap pengembangan dan implementasi. Subjek penelitian ini adalah ahli isi, desain, dan media pembelajaran serta 15 siswa kidal. Metode pengumpulan data yang digunakan yaitu tes, angket, wawancara, dan kuesioner. Teknik analisis data yang digunakan adalah deskriptif kuantitatif, deskriptif kualitatif, dan statistik deskriptif. Diperoleh bahwa hasil penilaian uji ahli isi pembelajaran sebesar $96,43 \%$, uji ahli desain pembelajaran sebesar 97,9\%, uji ahli media pembelajaran sebesar $97,5 \%$, uji coba perorangan sebesar $95,83 \%$, uji coba kelompok kecil sebesar $95,42 \%$, dan uji coba lapangan sebesar $94,67 \%$ yang keseluruhan persentase skornya dikualifikasikan sangat baik. Sedangkan hasil uji efektivitas dengan tes literasi diperoleh bahwa tes 1 memiliki rata-rata 68,1 yang dikategorikan sedang, tes 2 memiliki rata-rata 84,63 yang dikategorikan tinggi dan tes 3 memiliki rata-rata 92,78 yang dikategorikan sangat tinggi. Oleh karena itu buku ajar ini layak digunakan dan kemampuan literasi siswa kidal saat menggunakan buku ajar yang digubah sesuai dengan karakteristiknya ini semakin meningkat. Implikasi dari penelitian ini adalah memberikan kenyamanan bagi siswa kidal dalam menggunakan buku ajar dan memotivasi guru untuk memperhatikan keberagaman karakteristik yang dimiliki oleh siswa salah satunya adalah siswa kidal.
\end{abstract}

\begin{abstract}
A B S T R A C T
This research was conducted because until nowadays there has been no textbooks composition according to left-handed children characteristics. When left-handed children used conventional books, left-handed children felt uncomfortable in opening conventional books using their left hand. This development research was aimed to analyze effectiveness of composing textbooks based on Problem Based Learning thematic content of theme 1 sub-theme 1 for left-handed students class IV. This development research used Hannafin and Peck model which consisted of three stages; needs assessment, design, and development and implementation. The subjects of this study were content, design, and instructional media experts and 15 lefthanded students. This research using data collection methods; tests, questionnaires, and interviews. The data analysis technique used is descriptive quantitative, descriptive qualitative, and descriptive statistics. It is found that assessment result of learning content expert test of $96.43 \%$, learning design expert test of $97.9 \%$, learning media expert test of $97.5 \%$, individual trial of $95.83 \%$, small group trial of $95,42 \%$, and field trials of $94,67 \%$ which overall score percentage is qualified very well. Meanwhile, the effectiveness test result using literacy test shows that test 1 has an average of 68.1 which is categorized as moderate, test 2 has an average of 84.63 which is categorized as high and test 3 has an average of 92.78 which is categorized as very high. Therefore, it can be concluded that this textbook is suitable to use and literacy ability of lefthanded students when using the textbooks that are composed according to their characteristics is increasing
\end{abstract}




\section{PENDAHULUAN}

Setiap manusia yang dilahirkan pastinya memiliki perbedaan antara manusia yang satu dengan manusia yang lainnya mulai dari minat, bakat, gaya belajar, cara beraktivitas, dan sebagainya. Pada umumnya orang terbiasa mengambil sesuatu menggunakan tangan kanan atau lebih aktif menggunakan tangan kanan saat beraktivitas. Namun ada juga orang yang terbiasa mengambil sesuatu menggunakan tangan kiri atau lebih aktif menggunakan tangan kiri dalam beraktivitas. Orang yang terbiasa mengambil sesuatu menggunakan tangan kiri disebut dengan anak kidal. Kidal adalah kondisi saat seseorang lebih mendominasi menggunakan tubuh bagian kirinya (Mahardhika dan Sukardani, 2020; Syukri et al., 2021). Beberapa faktor anak menjadi kidal adalah pembiasaan yang salah, hemisphere (belahan otak) bagian kanan lebih unggul dibandingkan bagian kiri, faktor keturunan, dan posisi janin karena anak tersebut kembar (Drani, 2013; Nurwulan dan Kristiani 2020). Di dalam masyarakat barat kidal tidak banyak dipersoalkan, makan minum dengan tangan kiri bahkan menjadi budaya moderen.

Namun kenyataan dilapangan, jumlah siswa kidal yang sangat sedikit. Sehingga menyebabkan anak kidal harus beradaptasi dengan alat atau benda yang didesain bagi anak pada umumnya (Abdulqodir, Sriwarno dan Isdianto, 2014). Selain itu, anak kidal dipaksa untuk menggunakan tangan kanan dalam beraktivitas, hal ini menyebabkan anak mengalami gangguan psikologis, gagap dan bahkan bisa menyebabkan mengompol (Iriani, 2014; Hawkyard, Dempsey dan Arthur-Kelly, 2014). Berdasarkan hasil wawancara bersama enam siswa kidal di SD Gugus Jendral Sudirman Denpasar diperoleh bahwa siswa kurang nyaman dalam menggunakan buku ajar konvensional yang dibuka dari kanan ke kiri. Siswa kidal merasa kesulitan saat membuka buku konvensional menggunakan tangan kiri, karena siswa sering merasakan pegal sehingga berdampak kepada motivasi belajar siswa dan kemampuan literasi siswa yang berkurang. Sampai saat ini SD di Kota Denpasar belum memiliki buku ajar yang didesain khusus bagi siswa kidal. Berdasarkan hasil wawancara bersama guru kelas di SD Negeri 2 Serangan yang mengajar siswa kidal diperoleh informasi bahwa posisi badan siswa kidal saat menulis pada buku konvensional tidak tegak dan kecepatan membuka buku konvensional siswa kidal tergolong cukup lambat. Kecepatan membuka buku siswa kidal yang lambat disebabkan karena siswa kidal harus membuka buku konvensional menggunakan tangan kiri. Selain itu, berdasarkan hasil wawancara bersama guru bertangan kidal di SD Negeri 8 Kesiman diperoleh informasi bahwa lebih nyaman dalam membuka buku yang dibuka dari kiri ke kanan. Guru sangat berharap adanya buku ajar yang dirancang khusus sesuai dengan karakterisik siswa kidal yaitu dibuka dari kiri ke kanan sehingga siswa kidal dapat dengan nyaman mengikuti proses pembelajaran. Jika permasalahan tersebut tidak segera diatasi akan memberikan dampak terhadap proses pembelajaran siswa.

Solusi yang dapat dilakukan untuk mengatasi permasalahan tersebut yaitu menggunakan media, strategi, pendekatan, model dan buku ajar. Salah satu yang dapat diterapkan untu mengatasi masalah tersebut yaitu dengan menggunakan buku ajar. Buku ajar adalah bahan cetak yang dikembangkan sebagai sumber belajar siswa (Oktaviana et al., 2020; Prasetiyo \& Perwiraningtyas, 2017; Suplemen et al., 2017). Buku ajar membantu untuk dapat mempelajari materi secara sistematis dan terstruktur sehingga dapat menambah pengetahuan siswa (Putrantana et al., 2020; Safitri \& Nurkamilah, 2020). Buku ajar konvensional dibuka dari kanan ke kiri sehingga gerakan mendorong pada buku ajar konvensional adalah gerakan mendorong dari kanan ke kiri. Buku ajar yang sebaiknya digunakan oleh anak kidal adalah buku yang dibuka dari kiri ke kanan sehingga gerakan mendorongnya adalah gerakan tangan dari kiri ke kanan sesuai dengan karakteristiknya (Abdulqodir, Sriwarno dan Isdianto, 2014). Selain itu, sangat penting untuk menciptakan proses pembelajaran yang menyenangkan. Proses pembelajaran yang menyenangkan tercipta apabila mampu untuk memotivasi peserta didik aktif dalam mengikuti proses pembelajaran (Salu dan Tadius, 2018; Fakhrurrazi, 2018). Salah satu model pembelajaran yang mempu memotivasi peserta didik aktif dalam mengikuti proses pembelajaran dan mampu meningkatkan cara berpikir kritis siswa kidal adalah model pembelajaran Problem Based Learning. Model pembelajaran berbasis masalah atau Problem Based Learning adalah model pembelajaran yang dipusatkan kepada siswa dengan memberikan masalah dari dunia nyata pada awal pembelajaran (Rahmadani, 2019; Albab et al., 2021).

Beberapa penelitian sebelumnya menyatakan buku ajar ekologi berbasis Problem Based Learning ini sangat layak dan dapat digunakan dalam KBM ekologi (Nikmah et al., 2019). Buku ajar berbasis Problem Based Learning dapat meningkatkan kemampuan berpikir tingkat tinggi siswa (Novferma et al., 2018). Bahan ajar dapat membantu siswa dalam memahami materi pembelajaran (Hutama, 2016; Kurnia et al., 2019). Hingga saat ini penelitian mengenai penggubahan buku ajar bagi anak kidal belum pernah untuk dilaksanakan. Dengan menggunakan model Problem Based Learning, siswa kidal akan dihadapkan dengan permasalahan yang otentik untuk diselesaikan dengan segala pengetahuan yang dimilikinya atau menyelesaikannya dengan mencari berbagai sumber lainnya. Dengan demikian siswa kidal akan dilatih untuk terbiasa memecahkan masalah otentik sejak dini. Penelitian ini penting untuk dilakukan karena jika anak kidal dipaksanakan untuk menggunakan benda seperti buku ajar yang tidak sesuai dengan karakteristiknya maka dapat menganggu psikologis siswa dan juga berdampak kepada kemampuan literasinya yang berkurang. Penelitian pengembangan ini bertujuan untuk menciptakan buku ajar berbasis Problem Based Learning muatan tematik tema 1 subtema 1 kelas IV bagi siswa kidal kelas IV di SD. 


\section{METODE}

Jenis penelitian ini adalah penelitian pengembangan. Penelitian dilaksanakan di SD Kota Denpasar. Produk yang dikembangkan adalah Buku Ajar berbasis Problem Based Learning Muatan Tematik Tema 1 Subtema 1 bagi siswa kidal. Model pengembangan yang digunakan dalam penelitan ini adalah model Hannafin and Peck yang terdiri dari tiga tahapan yaitu tahap penilaian kebutuhan/analisis kebutuhan, tahap desain, dan tahap pengembangan dan implementasi (Tegeh dan Sudatha, 2019). Prosedur dari penelitian ini terdiri dari tiga tahap yang dimulai dari tahap pertama yaitu tahap analisis kebutuhan yang meliputi analisis masalah pembelajaran, analisis fasilitas, dan analisis kompetensi. Tahap kedua yaitu tahap desain yang meliputi pembuatan peta konsep dan kerangka buku ajar, pembuatan flowchart dan storyboard, pengumpulan dan penyusunan materi, penetapan aplikasi, penetapan desain tampilan, dan penyusunan angket buku ajar. Sedangkan pada tahap ketiga yaitu tahap pengembangan dan implementasi yang meliputi pendesainan buku ajar, uji ahli, revisi berdasarkan hasil uji ahli, uji coba siswa, revisi berdasarkan hasil uji coba siswa, dan uji efektivitas.

Desain uji coba produk dari penelitian ini adalah uji ahli dan uji coba kepada siswa. Uji ahli terdiri dari uji ahli isi pembelajaran, uji ahli desain pembelajaran, dan uji ahli media pembelajaran. Sedangkan uji coba kepada siswa terdiri dari uji perorangan, uji kelompok kecil, dan uji lapangan. Subjek dari uji ahli adalah satu orang ahli isi pembelajaran yang memiliki latar belakang pendidikan S2 Pendidikan Dasar serta satu orang ahli desain dan media pembelajaran yang memiliki latar belakang pendidikan S2 Teknologi Pembelajaran. Sedangkan subjek dari uji coba kepada siswa dan uji efektivitas adalah 15 siswa kidal yang berasal dari 11 sekolah dasar yang ada di Kota Denpasar. Produk buku ajar berbasis Problem Based Learning muatan Tematik Tema 1 Subtema 1 Kelas IV bagi siswa kidal ini direvisi berdasarkan masukan dan komentar dari ahli isi pembelajaran, ahli desain pembelajaran, dan ahli media pembelajaran. Setelah produk selesai direvisi kemudian dilanjutkan kepada tahap selanjutnya yaitu tahap uji coba kepada siswa. Uji coba kepada siswa meliputi uji coba perorangan, uji coba kelompok kecil, dan uji coba lapangan. Uji coba perorangan dilaksanakan kepada 3 orang siswa kidal, uji kelompok kecil dilaksanakan kepada 6 orang siswa kidal, dan uji coba lapangan dilaksanakan kepada 15 orang siswa kidal. Kemudian dilaksanakan revisi berdasarkan hasil uji coba kepada siswa sehingga buku ajar dapat dikatakan layak untuk digunakan. Setelah buku ajar selesai direvisi dan dikatakan layak, tahap selanjutnya adalah uji efektivitas. Uji efektivitas dilaksanakan dengan metode time series. Time series adalah data yang disusun berdasarkan urutan waktu tertentu untuk mengukur berbagai perubahan atau perkembangan dalam periode tertentu (Faradiba, 2020). Uji efektivitas dilakukan dengan melaksanakan tes literasi sebanyak tiga kali kepada siswa kidal dengan indikator memahami isi bacaan, memperoleh informasi dari isi bacaan, mendapatkan banyak pengetahuan baru, merefleksikan atau menceritakan isi bacaan, mendapatkan banyak pengetahuan baru, merefleksikan atau menceritakan isi bacaan, dan membuat kesimpulan secara tertulis. Sebelum melaksanakan tes literasi, instrumen diuji coba terlebih dahulu kemudian dihitung validitas, dan reliabilitas.

Metode pengumpulan data yang digunakan dalam penelitian ini adalah tes, angket/kuesioner, observasi, dan wawancara tidak berstruktur dengan instrumen pengumpulan datanya adalah tes dan kuesioner. Metode tes digunakan untuk mengukur kemampuan literasi siswa kidal. Metode angket digunakan untuk uji ahli dan uji coba siswa. Metode observasi digunakan untuk mengamati perilaku siswa kidal sebelum dan saat menggunakan buku ajar yang digubah sesuai dengan karakteristik siswa kidal. Metode wawancara tidak berstuktur digunakan di awal penelitian untuk mengetahui pendapat siswa kidal dalam menggunakan buku konvensional. Instrumen yang digunakan dalam penelitian ini adalah instrumen tes literasi dan instrumen berupa angket untuk uji ahli dan uji coba siswa. Kisi-kisi instrumen angket yang digunakan dalam penelitian ini disajikan pada Tabel 1.

Tabel 1 Kisi-Kisi Instrumen Angket

\begin{tabular}{|c|c|c|c|c|}
\hline \multicolumn{5}{|c|}{ Indikator Angket } \\
\hline Ahli Isi Pembelajaran & & $\begin{array}{c}\text { Ahli Desain } \\
\text { Pembelajaran }\end{array}$ & $\begin{array}{c}\text { Ahli Media } \\
\text { Pembelajaran }\end{array}$ & $\begin{array}{l}\text { Uji Perorangan, Uji Kelompok } \\
\text { Kecil, dan Uji Lapangan }\end{array}$ \\
\hline 1. Kompetensi Dasar & 1. & Kejelasan tujuan & 1. Jenis huruf & $\begin{array}{l}\text { 1. Kemenarikan tampilan } \\
\text { buku ajar }\end{array}$ \\
\hline 2. Indikator & 2. & $\begin{array}{l}\text { Konsistensi antara } \\
\text { tujuan, materi dan } \\
\text { evaluasi }\end{array}$ & $\begin{array}{l}\text { 2. Keterbacaan } \\
\text { teks }\end{array}$ & $\begin{array}{l}\text { 2. Kemudahan memahami } \\
\text { materi yang disajikan }\end{array}$ \\
\hline 3. Tujuan & 3. & $\begin{array}{l}\text { Penyampaian } \\
\text { materi. }\end{array}$ & $\begin{array}{l}\text { 3. Gambar } \\
\text { mendukung } \\
\text { pemahaman } \\
\text { materi }\end{array}$ & 3. Kejelasan uraian materi \\
\hline 4. Kebenaran materi & 4. & $\begin{array}{l}\text { Kegiatan } \\
\text { pembelajaran }\end{array}$ & $\begin{array}{l}\text { 4. Tata letak } \\
\text { gambar }\end{array}$ & $\begin{array}{l}\text { 4. Kesesuaian materi dengan } \\
\text { kehidupan nyata siswa }\end{array}$ \\
\hline 5. Ketepatan materi & 5. & Pemberian contoh & $\begin{array}{l}\text { 5. Kualitas atau } \\
\text { resolusi gambar }\end{array}$ & $\begin{array}{l}\text { 5. Kualitas teks yang } \\
\text { digunakan }\end{array}$ \\
\hline
\end{tabular}




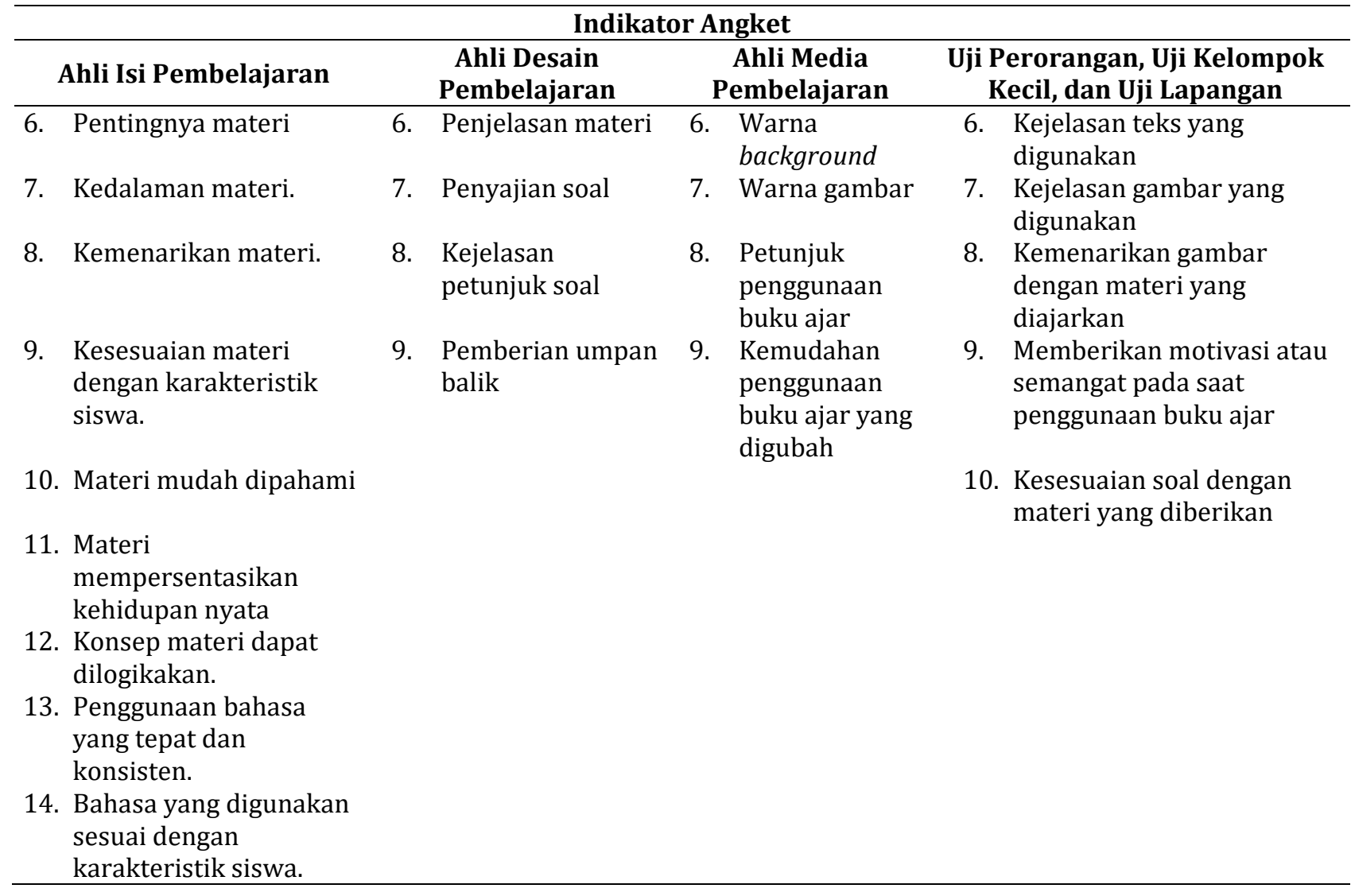

Penelitian ini menggunakan tiga teknik analisis data yaitu analisis deskriptif kuantitatif, analisis deskriptif kualitatif, dan analisis statistik deskriptif. Analisis deskriptif kuantitatif adalah cara pengolahan data dengan menyusun dalam bentuk angka secara sistematis sehingga diperoleh kesimpulan (Agung, 2018). Analisis deskriptif kuantitatif ini digunakan untuk mengolah data yang berasal dari uji ahli, uji coba kepada siswa, dan uji efektivitas. Data yang diperoleh berdasarkan pembagian angket dianalisis menggunakan skala likert pada Tabel 2.

Tabel 2. Skala likert (Sukardi, 2008)

\begin{tabular}{ccc}
\hline No. & Skor & Keterangan \\
\hline 1. & Skor 1 & Sangat tidak setuju \\
2. & Skor 2 & Tidak setuju \\
3. & Skor 3 & Setuju \\
4. & Skor 4 & Sangat Setuju \\
\hline
\end{tabular}

Analisis deskriptif kualitatif adalah cara pengolahan data dengan menyusun dalam bentuk kalimat/kata secara sistematis sehingga diperoleh kesimpulan (Agung, 2018). Analisis deskriptif kualitatif ini digunakan untuk menganalisis saran, kritik, komentar, hasil wawancara, dan sebagainya. Analisis statistik deskriptif yang digunakan dalam penelitian ini adalah mean (rata-rata). Rumus mean digunakan unuk menghitung rata-rata persentase skor hasil uji ahli, hasil uji coba siswa, dan uji efektivitas berupa rata-rata hasil tes literasi siswa dalam setiap periodenya. Untuk dapat mengambil keputusan dan memberikan makna maka digunakan ketetapan pada Tabel 3.

Tabel 3. Konversi Tingkat Pencapaian dengan Skala 5 (Agung, 2018)

\begin{tabular}{ccccc}
\hline No & Tingkat Pencapaian & Nilai Angka & Kualifikasi & Keterangan \\
\hline 1 & $90-100 \%$ & 4 & Sangat Baik & Sangat layak/sangat valid \\
2 & $80-89 \%$ & 3 & Baik & Layak/valid \\
3 & $65-79 \%$ & 2 & Cukup & Kurang layak/kurang valid \\
4 & $55-64 \%$ & 1 & Kurang & Tidak layak/tidak valid \\
5 & $0-54 \%$ & 0 & Sangat Kurang & Sangat tidak layak/sangat tidak \\
& & & & valid \\
\hline
\end{tabular}




\section{HASIL DAN PEMBAHASAN}

Hasil

Penelitian ini menggubah buku ajar berbasis Problem Based Learning sesuai dengan karakteristik siswa kidal yaitu dibuka dari kiri ke kanan. Rancang bangun penggubahan buku ajar ini menggunakan model pengembangan Hannafin and Peck yang terdiri dari tiga tahap yaitu tahap analisis kebutuhan, tahap desain, serta tahap pengembangan dan implementasi. Tahap pertama yaitu tahap analisis yang terdiri dari tiga langkah yaitu analisis karakteristik dan masalah pembelajaran, analisis kompetensi, dan analisis fasilitas. Berdasarkan hasil analisis karakteristik dan masalah pembelajaran diperoleh bahwa siswa kidal kurang nyaman saat membuka buku konvensional menggunakan tangan kirinya. Selain itu, guru siswa kidal juga menyampaikan bahwa kecepatan membuka buku siswa kidal pada buku konvensional tergolong masih lambat dan posisi badannya saat menulis pada buku konvensional yang dianggap kurang tegak. Selain itu, berdasarkan hasil wawancara bersama guru bertangan kidal diperoleh bahwa beliau lebih nyaman dalam membuka buku ajar yang dibuka dari kiri ke kanan namun hingga saat ini belum ada buku ajar yang dibuka dari kiri ke kanan bagi anak kidal. Kemudian pada analisis kompetensi dilaksanakan analisis instruksional terkait dengan kompetensi yang dituntut tercapai kepada peserta didik pada kelas IV Tema 1 Indahnya Kebersamaan, Subtema 1 Keberagaman Budaya Bangsaku. Sedangkan berdasarkan hasil analisis fasilitas diperoleh bahwa SD di Kota Denpasar belum memiliki buku ajar yang digubah sesuai dengan karakteristik siswa kidal.

Tahap kedua yaitu tahap desain. Pada tahap desain ini dilakukan enam langkah yaitu pembuatan peta konsep dan kerangka buku ajar, pembuatan flowchart dan storyboard, pengumpulan berbagai bahan yang diperlukan dalam penyusunan buku ajar, penetapan aplikasi yang akan digunakan untuk merancang dan mendesain buku ajar yaitu Microsoft Word 2013, Adobe Photoshop CS3, dan Adobe Reader, penetapan desain tampilan buku ajar, dan penyusunan instrumen penilaian buku ajar yang meliputi angket uji ahli, angket uji coba kepada siswa dan instrumen tes literasi. Flowchart dan storyboard ini yang dijadikan sebagai salah satu acuan untuk mengembangkan buku ajar bagi siswa kidal. Tahap ketiga yaitu tahap pengembangan dan implementasi. Pada tahap ketiga pengembangan dan implementasi ini dilaksanakan beberapa kegiatan yang diawali dengan penulisan konten buku ajar berbasis Problem Based Learning kelas IV Tema 1 Subtema 1. Penulisan konten buku ajar dimulai dari pendahuluan, pembelajaran 1-6 hingga kepada penutup buku ajar. Pada saat konten atau materi dari buku ajar telah rampung barulah dilakukan pendesainan buku ajar sesuai dengan karakteristik anak kidal yaitu dibuka dari kiri ke kanan. Buku ajar dibuat dengan full colour dan dididukung dengam gambargambar yang menarik. Terdapat beberapa aplikasi yang digunakan untuk mendesain buku ajar bagi siswa kidal yaitu Microsoft Word 2013, Adobe Photoshop CS3, dan Adobe Reader. Pengembangan buku ajar dilakukan berpedoman dengan flowchart dan storyboard yang telah dirancang sebelumnya.

Uji ahli dilaksanakan kepada ahli isi pembelajaran, ahli desain pembelajaran, dan ahli media pembelajaran. Ahli isi pembelajaran yaitu guru SD di Kota Denpasar yang memiliki latar belakang pendidikan S2 Pendidikan Dasar sedangkan ahli desain pembelajaran dan ahli media pembelajaran yaitu dosen Universitas Pendidikan yang memiliki latar belakang pendidikan S2 Teknologi Pembelajaran. Setelah uji ahli, dilaksanakan uji coba kepada siswa melalui uji coba perorangan, uji coba kelompok kecil, dan uji coba lapangan. Uji coba perorangan dilaksanakan kepada tiga orang siswa kidal di SD Kota Denpasar dengan rincian satu orang siswa dengan kemampuan literasi rendah, satu orang siswa dengan kemampuan literasi sedang, dan satu orang dengan kemampuan literasi tinggi. uji coba kelompok kecil dilaksanakan kepada enam orang siswa kidal di SD Kota Denpasar dengan rincian dua orang siswa dengan kemampuan literasi rendah, dua orang siswa dengan kemampuan literasi sedang, dan dua orang dengan kemampuan literasi tinggi. Sedangkankan uji coba lapangan dilaksanakan kepada lima belas orang siswa kidal di SD Kota Denpasar dengan rincian lima orang siswa dengan kemampuan literasi rendah, lima orang siswa dengan kemampuan literasi sedang, dan lima orang dengan kemampuan literasi tinggi. Hasil uji ahli dan uji coba kepada siswa disajikan pada Tabel 4.

Tabel 4. Persentase Hasil Uji Coba Buku Ajar

\begin{tabular}{llcll}
\hline No. & \multicolumn{1}{c}{ Subjek Uji Coba } & Hasil & Kualifikasi & Keterangan \\
\hline 1. & Uji Ahli Isi Pembelajaran. & 96,43 & Sangat Baik & Layak untuk digunakan \\
2. & Uji Ahli Desain Pembelajaran. & 97,9 & Sangat Baik & Layak untuk digunakan \\
3. & Uji Ahli Media Pembelajaran. & 97,5 & Sangat Baik & Layak untuk digunakan \\
4. & Uji Coba Perorangan & 95,83 & Sangat Baik & Layak untuk digunakan \\
5. & Uj Coba Kelompok Kecil & 95,42 & Sangat Baik & Layak untuk digunakan \\
6. & Uji Coba Lapangan & 94,67 & Sangat Baik & Layak untuk digunakan \\
\hline
\end{tabular}

Berdasarkan hasil penilaian oleh ahli isi pembelajaran diperoleh persentase 96,43\% yang dikualifikasikan sangat baik. Selain itu, berdasarkan kesimpulan yang diberikan oleh ahli isi pembelajaran diperoleh bahwa produk buku ajar ini layak untuk digunakan. Hasil penilaian oleh ahli desain pembelajaran diperoleh persentase 97,9\% yang dikualifikasikan sangat baik. Kesimpulan yang diberikan oleh ahli desain pembelajaran diperoleh bahwa produk buku ajar ini layak untuk digunakan. Hasil penilaian oleh ahli media 
pembelajaran diperoleh persentase 97,5\% yang dikualifikasikan sangat baik. Kesimpulan yang diberikan oleh ahli media pembelajaran diperoleh bahwa produk buku ajar ini layak untuk digunakan. Hasil uji coba perorangan memperoleh persentase skor 95,83 yang dikualifikasikan sangat baik. Hasil uji coba kelompok kecil memperoleh persentase skor 95,42 yang dikualifikasikan sangat baik. Hasil uji coba lapangan memperoleh persentase skor 94,67 yang dikualifikasikan sangat baik. Dari hasil uji ahli dan uji coba kepada siswa diperoleh bahwa produk buku ajar bagi siswa kidal yang dikembangkan layak digunakan dalam proses pembelajaran. Dalam pelaksanaan uji coba ini terdapat komentar yang diberikan oleh ahli isi pembelajaran, ahli desain pembelajaran, dan ahli media pembelajaran yang dapat dijadikan sebagai pertimbangan untuk menyempurnakan produk. Komentar yang bersifat revisi dari ahli disajikan pada Tabel 5.

Tabel 5. Komentar Uji Coba Produk

\begin{tabular}{|c|c|c|c|}
\hline No. & Subjek Uji Coba & Komentar & Revisi \\
\hline 1. & $\begin{array}{l}\text { Ahli } \\
\text { Pembelajaran }\end{array}$ & $\begin{array}{l}\text { Perhatikan penggunaan cetak } \\
\text { miring pada kata yang } \\
\text { menggunakan bahasa daerah dan } \\
\text { bahasa asing. }\end{array}$ & $\begin{array}{l}\text { Mencetak miring kalimat/kata yang } \\
\text { berasal dari bahasa daerah dan bahasa } \\
\text { asing, }\end{array}$ \\
\hline 2. & $\begin{array}{l}\text { Ahli Desain } \\
\text { Pembelajaran }\end{array}$ & $\begin{array}{l}\text { Petunjuk soal pilihan ganda agar } \\
\text { diperjelas. }\end{array}$ & $\begin{array}{l}\text { Memperjelas petunjuk soal pilihan ganda } \\
\text { dengan menambahkan kalimat "Berilah } \\
\text { tanda silang (X)" pada petunjuk soal } \\
\text { pilihan ganda. } \\
\text { Menambahkan kata "petunjuk :" pada } \\
\text { petunjuk soal essay. }\end{array}$ \\
\hline 3. & $\begin{array}{l}\text { Ahli Media } \\
\text { Pembelajaran }\end{array}$ & $\begin{array}{l}\text { Tulisan pada punggung cover buku } \\
\text { terbalik. }\end{array}$ & $\begin{array}{l}\text { Membalik tulisan yang terdapat pada } \\
\text { punggung cover buku. }\end{array}$ \\
\hline
\end{tabular}

Langkah selanjutnya pada tahap pengembangan dan implementasi setelah produk dinyatakan layak adalah melakukan uji efektivitas. Uji efektivitas dilaksanakan dengan menggunakan time series dengan memberikan tes literasi sebanyak tiga kali kepada 15 siswa kidal di SD Kota Denpasar. Sebelum instrumen digunakan untuk tes, instrumen telah diuji coba sehingga diketahui validitas dan reliabilitas. Validitas dihitung dengan menggunakan rumus Product Moment diperoleh bahwa 9 butir tes memiliki nilai $r_{x y}>r_{\text {tabel }}$ sehingga 9 butir dinyatakan valid dan digunakan dalam tes literasi. Reliabilitas dihitung menggunakan rumus AlphaCronbach diperoleh bahwa nilai dari $\mathrm{r}_{1.1}$ adalah 0,93 yang tergolong dalam derajat reliabilitas tinggi. Uji efektivitas bertujuan untuk mengetahui pengaruh penggubahan buku ajar berbasis Problem Based Learning Tema 1 Subtema 1 terhadap kemampuan literasi siswa kidal di SD Kota Denpasar. Hasil tes kemampuan literasi siswa kidal setelah menggunakan buku ajar yang digubah sesuai dengan karakteristik siswa kidal kelas IV SD disajikan pada Tabel 6.

Tabel 6. Hasil Tes Literasi

\begin{tabular}{cccc}
\hline No. & Periode Tes & Rata-Rata Skor & Kualifikasi \\
\hline 1. & Tes 1 & 68,1 & Sedang \\
2. & Tes 2 & 84,63 & Tinggi \\
3. & Tes 3 & 92,78 & Sangat Tinggi \\
\hline
\end{tabular}

Terlihat dari tabel 6 bahwa terjadi peningkatan rata-rata hasil tes literasi siswa kidal saat menggunakan buku ajar berbasis Problem Based Learning yang digubah sesuai dengan karakteristik siswa kidal. Tes 1 memiliki rata-rata 68,1 yang dikualifikasikan sedang, tes 2 memiliki rata-rata 84,63 yang dikualifikasikan tinggi, dan tes 3 memiliki rata-rata 92,78 yang dikualifikasikan sangat tinggi. Jadi dapat disimpulkan bahwa buku ajar kidal mampu meningkatkan kemampuan literasi siswa kidal kelas IV di SD Kota Denpasar.

\section{Pembahasan}

Berdasarkan hasil penelitian diperoleh bahwa penggubahan buku ajar berbasis Problem Based Learning Tema 1 Subtema 1 bagi siswa kidal memperoleh kualifikasi sangat baik berdasarkan hasil uji ahli dan uji coba kepada siswa sehingga produk ini dinyatakan layak untuk digunakan dalam proses pembelajaran. Produk ini dikembangkan dengan menggunakan model Hannafin and Peck. Model Hannafin and Peck merupakan model pengembangan yang beorientasi kepada pengembangan produk sehingga sangat sesuai jika digunakan dalam pengembangan buku ajar (Iza dan Anantyarta, 2018; Kholidin, 2017). Model Hannafin and Peck memiliki langkah yang sistematis dalam pengembangan sebuah produk. Model ini diawali dengan menganalisis permasalahan 
yang ada di lapangan sehingga menjadi dasar dalam pengembangan produk kemudian mendesain serta mengembangkan dan implementasikan produk.

Berdasarkan hasil penelitian pada tahap uji coba produk oleh ahli isi pembelajaran tematik diperoleh bahwa materi pada buku ajar memperoleh hasil dengan kualifikasi sangat baik dengan kesimpulan dari ahli isi pembelajaran bahwa buku ajar ini layak untuk digunakan dalam proses pembelajaran. Dalam penilaian isi pembelajaran terdapat tiga aspek yang dinilai yaitu kurikulum, materi, dan aspek tata bahasa. Pada aspek materi yang menilai materi yang disajikan benar dan akurat, materi disajikan dengan tepat, materi penting untuk dipelajari, materi disajikan mendalam, materi disajikan menarik, materi sesuai dengan karakteristik siswa, materi mudah dipahami siswa, dan sesuai dengan prinsip Problem Based Learning diperoleh skor 4 yang berarti sangat disetujui oleh ahli sedangkan pernyataan materi memiliki keterkaitan dengan kehidupan nyata siswa diperoleh skor 3 yang berarti disetujui oleh ahli. Pada aspek bahasa yang menilai penggunaan bahasa tepat dan konsisten diperoleh skor 4 yang berarti sangat disetujui oleh ahli sedangkan indikator bahasa sesuai dengan karakteristik siswa diperoleh skor 3 yang berarti disetujui oleh ahli. Buku ajar ini memuat materi tematik yang memadukan beberapa mata pelajaran yaitu Bahasa Indonesia, IPS, PPKn, IPA, dan SBdP sehingga siswa akan lebih mudah memahami materi dan siswa akan mendapatkan pembelajaran yang lebih bermakna. Dengan pembelajaran tematik, pembelajaran menjadi lebih nyata sehingga siswa akan lebih mudah dalam memahami materi pelajaran (Widiyanto, 2017; Effendi dan Reinita, 2020). Pembelajaran bermakna akan memudahkan siswa memahami materi yang bersifat abstrak (Ariani, 2020; Soekisno, 2015). Oleh karena itu, bahan ajar ini dapat digunakan pada proses pembelajaran, untuk membantu siswa.

Berdasarkan hasil penilaian oleh ahli desain pembelajaran bahwa produk buku ajar ini layak untuk digunakan. Berdasarkan hasil uji ahli desain pembelajaran pada aspek tujuan yang menilai tujuan pembelajaran dapat dicapai melalui buku ajar, tujuan pembelajaran sesuai dengan format ABC, tujuan selaras dengan materi, serta tujuan, materi dan soal selaras keseluruhan mendapatkan skor 4 yang berarti sangat disetujui oleh ahli. Pada aspek strategi yang menilai penyampaian materi sesuai dengan langkah yang logis, penyampaian materi memberikan alur navigasi yang bebas, penyampaian materi memberikan motivasi, materi disertai dengan contoh yang jelas, penyajian materi sesuai karakteristik siswa, dan penyajian mampu menarik perhatian siswa keseluruhan mendapatkan skor 4 yang berarti sangat disetujui oleh ahli. Sedangkan pada aspek evaluasi yang menilai soal yang diberikan sesuai dengan indikator pembelajaran mendapatkan skor 4 yang berarti sangat disetujui oleh ahli sedangkan pernyataan petunjuk dalam mengerjakan soal jelas mendapatkan skor 3 yang berarti disetujui oleh ahli. Komentar yang diberikan oleh ahli berkaitan dengan petunjuk soal pilihan ganda agar diperjelas. Instrumen harus dilengkapi dengan petunjuk soal yang jelas sehingga nantinya siswa tidak kebinggungan dalam memberikan respon dari soal (Nasution 2016; Helendra dan Sar, 2021). Buku ajar ini dirancang berbasis Problem Based Learning sehingga siswa lebih aktif dalam proses pembelajaran dan ingatan siswa mengenai materi yang dipelajarinya akan lebih lama. Pada saat siswa aktif dalam proses pembelajaran siswa akan menemukan pengetahuannya sendiri sehingga ingatan siswa mengenai materi tersebut akan lebih lama (Rahayu dan Hidayati, 2018; Astuti dan Sari, 2017). Selain itu, dengan dirancangnya buku ajar berbasis Problem Based Learning ini akan melatih kemampuan berpikir kritis siswa, melatih kemampuan memecahkan masalah nyata, dan melatih siswa aktif dalam proses pembelajaran (Shofiyah dan Wulandari, 2018; Rahayu dan Ismawati, 2019).

Berdasarkan hasil penilaian oleh ahli media pembelajaran diperoleh bahwa produk buku ajar ini layak untuk digunakan. Berdasarkan hasil uji ahli media pembelajaran pada aspek teks yang menilai kesesuaian pemilihan jenis huruf, kejelasan teks, dan teks disajikan dengan tepat, keseluruhan mendapatkan skor 4 yang berarti sangat disetujui oleh ahli. Pada aspek gambar yang menilai penggunaan gambar mendukung pemahaman materi dan kualitas gambar standar mendapatkan skor 4 yang berarti sangat disetujui oleh ahli sedangkan tata letak gambar sesuai sesuai memperoleh skor 3 yang berarti disetujui oleh ahli. Pada aspek warna yang menilai warna latar belakang sesuai dan warna gambar jelas, keseluruhan memperoleh skor 4 yang berarti sangat disetujui oleh ahli. Pada aspek teknis yang menilai petunjuk penggunaan buku yang jelas dan buku ajar yang mudah digunakan bagi siswa kidal, keseluruhan memperoleh skor 4 yang berarti sangat disetujui oleh ahli. Masukan yang diberikan oleh ahli media pembelajaran adalah sebaiknya tulisan pada punggung buku di balik. Tulisan harus ditata sedemikian rupa agar tidak menggangu materi yang disajikan (Ulfah dan Jumaiyah 2018). Jenis huruf yang paling dominan digunakan dalam buku ajar ini adalah Open Sans yang tergolong dalam jenis font Sans Serif. Penggunaan huruf yang sebaiknya digunakan dalam pembuatan produk pembelajaran adalah kelompok jenis font Sans Serif (Sudarma, 2015). Kelebihan dari kelompok jenis sans serif adalah huruf standar tanpa adanya sentuhan kreatif sehingga lebih mudah dibaca dari jarak jauh maupun dari jarak dekat (Arifrahara, 2021; Pratama dan Swasty, 2018). Hal inilah yang menyebabkan siswa kidal lebih mudah dalam membaca buku ajar yang dikembangkan ini sehingga siswa akan merasa nyaman dalam membacanya.

Berdasarkan hasil uji coba perorangan yang melibatkan tiga siswa kidal diperoleh bahwa buku ajar yang dikembangkan memperoleh hasil yang dikualifikasikan sangat baik. Hasil uji coba kelompok kecil yang melibatkan enam siswa kidal diperoleh bahwa buku ajar yang dikembangkan memperoleh hasil yang dikualifikasikan sangat baik. Hasil uji coba kelompok kecil yang melibatkan lima belas siswa kidal diperoleh bahwa buku ajar yang dikembangkan memperoleh hasil yang dikualifikasikan sangat baik. Pada uji coba ini 
siswa memberikan komentar positif terkait dengan buku ajar yang sedang dikembangkan. Siswa merasa senang karena dengan penggubahan buku ajar ini siswa menjadi lebih mudah dalam membuka buku. Hal ini karena buku ajar sudah digubah sesuai dengan karakteristik anak kidal yaitu dibuka dari kiri ke kanan yang sejalan dengan penelitian oleh (Abdulqodir et al., 2014) bahwa gerakan mendorong dari anak kidal adalah gerakan tangan dari kiri ke kanan. Pada saat seseorang merasa nyaman dalam menggunakan suatu produk maka orang tersebut akan senang dalam menggunakannya (Palma dan Andjarwati 2016; Dakhi 2020). Selain itu, siswa kidal merasa tertarik dalam menggunakan buku ajar ini karena buku ajar ini didesain penuh warna (full colour) dan berisi gambar-gambar yang menarik. Gambar yang menarik dapat menarik perhatian siswa dan mempermudah siswa dalam memahami materi (Ulfaeni, 2018; Damayanti, 2018).

Berdasarkan hasil uji efektivitas berupa tes kemampuan literasi yang melibatkan 15 siswa kidal diperoleh bahwa hasil tes 1 dikualifikasikan sedang, tes 2 dikualifikasikan tinggi, dan tes 3 dikualifikasikan sangat tinggi. Hal ini berarti kemampuan literasi siswa kidal saat menggunakan buku ajar yang digubah ini semakin meningkat karena buku ajar telah digubah sesuai dengan karakteristik siswa kidal sehingga minat baca siswa juga semakin meningkat. Buku ajar harus memiliki daya tarik yang kuat sehingga akan mempengaruhi minat baca siswa terhadap buku tersebut (Kurniawan dan Masjudin, 2017; Gani et al., 2020). Berdasarkan hasil observasi diperoleh bahwa arah pandang siswa kidal dimulai dari kanan ke kiri dan 12 dari 15 siswa kidal posisi badannya lebih tegak dalam menulis pada buku kidal dibandingkan pada buku konvensional. Selain itu, rata-rata kecepatan membuka buku konvensional menggunakan tangan kiri adalah 34,6 detik sedangkan rata-rata kecepatan membuka buku kidal menggunakan tangan kiri adalah 20,53 detik. Hal ini berarti siswa kidal lebih cepat membuka buku kidal dibandungkan dengan buku konvensional. Faktor arah pandang, posisi badan, dan kecepatan membuka buku ini juga mempengaruhi peningkatkan kemampuan literasi siswa kidal saat menggunakan buku ajar yang digubah sesuai dengan karakteristik siswa kidal. Anak kidal memiliki otak belahan kanan yang lebih dominan dibandingkan dengan otak belahan kiri (Drani, 2013; Mulyaningsih, 2015). Otak belahan kanan berhubungan dengan kreativitas (Fuadaturahmah, 2019; Sukmaangara, Muhtadi, dan Madawistama, 2021). Hal inilah yang menyebabkan tidak jarang anak kidal memiliki kreativitas yang cukup tinggi. Anak kidal umumnya adalah anak yang berpikir divergen karena mengutamakan kreativitas dan mengeksplorasi berbagai solusi untuk memecahkan suatu masalah. Dengan dibuatnya buku ajar berbasis Problem Based Learning bagi siswa kidal ini maka akan semakin melatih kemampuan berpikir kritis dan berpikir divergen bagi anak kidal sehingga anak kidal semakin dapat mengembangkan potensi yang dimilikinya.

Berdasarkan hasil penelitian yang telah dibahas bahwa penggubahan buku ajar berbasis Problem Based Learning Tematik Tema 1 Subtema 1 layak digunakan dalam proses pembelajaran dan mampu meningkatkan kemampuan literasi siswa kidal saat menggunakannya. Temuan ini diperkuat dengan temuan penelitian sebelumnya yang menyatakan bahan ajar dapat membantu guru dalam menyampaikan materi kepada siswa (Bock et al., 2018; Firman et al., 2018). Temuan lain juga menyatakan bahan ajar dapat membantu siswa dalam memahami materi (Krismawati, 2019; Muga \& D.N.L., 2017). Bahan ajar berbasis problem based learning efektif dan layak digunakan pada proses pembelajaran (Muga \& D.N.L., 2017; Saidah et al., 2014). Buku ajar berbasis Problem Based Learning layak dan efektif digunakan dalam proses pembelajaran (Aprilia, Apreasta, dan Prasetyo 2021; Devirita, Neviyarni, dan Daharnis 2021). Kelebihan dari penelitian ini adalah mengembangkan buku ajar sesuai dengan karakteristik siswa kidal. Dengan adanya penelitian ini diharapkan berbagai pihak mulai memperhatikan siswa kidal yang memiliki karakteristik berbeda dari anak pada umumnya sehingga siswa kidal dapat menggunakan produk pembelajaran sesuai dengan karakteristiknya. Implikasi dari penelitian ini adalah memberikan kenyamanan bagi siswa kidal dalam menggunakan buku ajar dan memotivasi guru untuk memperhatikan keberagaman karakteristik yang dimiliki oleh siswa salah satunya adalah siswa kidal. Penelitian ini terbatas pada penggubahan buku ajar berbasis Problem Based Learning muatan Tematik Tema 1 Subtema 1 bagi siswa kidal sehingga diharapkan peneliti lainnya dapat mengembangakan berbagai produk pembelajaran bagi siswa kidal.

\section{Simpulan}

Penelitian pengembangan produk buku ajar berbasis Problem Based Learning muatan Tematik Tema 1 Subtema 1 Kelas IV bagi siswa kidal dengan menerapkan model pengembangan Hannafin and Peck yang melalui tiga tahapan yaitu tahap analisis kebutuhan, tahap desain, serta tahap pengembangan dan implementasi sudah menghasilkan buku ajar yang layak digunakan dalam proses pembelajaran bagi siswa kidal dan buku ajar yang mampu meningkatkan kemampuan literasi siswa kidal saat menggunakan buku ajar yang digubah sesuai dengan karakteristik siswa kidal. Implikasi dari penelitian ini adalah memberikan kenyamanan bagi siswa kidal dalam menggunakan buku ajar dan memotivasi guru untuk memperhatikan keberagaman karakteristik yang dimiliki oleh siswa salah satunya adalah siswa kidal. 


\section{Daftar Pustaka}

Abdulqodir, A., Sriwarno, A. B., \& Isdianto, B. (2014). Kemampuan Adaptasi Orang Kidal terhadap Lingkungan Non Kidal dalam Aktivitas Menulis dan Menggambar (Studi Kasus: Mahasiswa/i FSRD-ITB). ITB Journal of Visual Art and Design, 6(1), 43-57. https://doi.org/10.5614/itbj.vad.2014.6.1.5.

Agung, A. A. G. (2018). Metodologi Penelitian Kuantitatif (Perspektif Manajemen Pendidikan). Universitas Pendidikan Ganesha.

Albab, U., Purnamasari, H., \& Isman, S. (2021). Pengaruh Media Aplikasi Paket Tracer Melalui Model Pembelajaran Problem Based Learning Terhadap Motivasi Dan Hasil Belajar Mata Pelajaran Admnistrasi Infrastruktur Jaringan Siswa Kelas Xi Tkj Di Smkn 2 Bangkalan. Jurnal Teladan, 6(2), 85-94. http://journal.unirow.ac.id/index.php/teladan/article/view/269.

Aprilia, W., Apreasta, L., \& Prasetyo, D. E. (2021). Pengembangan Buku Ajar Berbasis Model Problem Based Learning pada Subtema 1 Kekayaan Sumber Energi Di Indonesia pada kelas IV Sekolah Dasar. INNOVATIVE: Journal Of Social Science Research, 1(2), 48-54. https://doi.org/10.31004/innovative.v1i2.2084.

Ariani, T. (2020). Analysis of Students' Critical Thinking Skills in Physics Problems. Physics Educational Journal, 3(1), 1-13. https://doi.org/10.37891/kpej.v3i1.119.

Arifrahara, G. (2021). Analisis Penggunaan Tipografi Spasial Sans Serif Dalam Ruang Publik Taman Tematik Kota Bandung. ANDHARUPA: Jurnal Desain Komunikasi Visual \& Multimedia, 7(01), 92-104. https://doi.org/10.33633/andharupa.v7i01.3804.

Astuti, A., \& Sari, N. (2017). Pengembangan Lembar Kerja Siswa (Lks) Pada Mata Pelajaran Matematika Siswa Kelas X Sma. Jurnal Cendekia: Jurnal Pendidikan Matematika, 1(2), 13-24. https://doi.org/10.31004/cendekia.v1i2.16.

Bock, A., Modabber, A., Kniha, K., Lemos, M., Rafai, N., \& Hölzle, F. (2018). Blended learning modules for lectures on oral and maxillofacial surgery. British Journal of Oral and Maxillofacial Surgery, 56(10), 956-961. https://doi.org/10.1016/j.bjoms.2018.10.281.

Budianingsih, T. (2017). Peran Neurolinguistik dalam Pengajaran Bahasa. Jurnal Al-Azhar Indonesia Seri Humaniora, 3(2), 137. https://doi.org/10.36722/sh.v3i2.203.

Dakhi, A. S. (2020). Kiat Sukses Meningkatkan Disiplin Siswa. Deepublish Publisher.

Damayanti, D. (2018). Layanan Informasi dengan Media Gambar untuk Meningkatkan Pemahaman Sex Education Siswa. Indonesian Journal of Guidance And Counseling: Theory And Application, 7(1), 37-44. https://doi.org/10.15294/IJGC.V8I1.22056.

Devirita, F., Neviyarni, N., \& Daharnis, D. (2021). Pengembangan Buku Ajar Berbasis Problem Based Learning di Sekolah Dasar. Jurnal Basicedu, 5(2), 469-478. https://doi.org/10.31004/basicedu.v5i2.680.

Drani, A. (2013). Gangguan Berbahasa Afasia Motorik Pada Penderita Gangguan Tumor Kepala Pada Usia Dewasa. Journal of Chemical Information and Modeling, 53(9), 1689-1699. https://doi.org/10.24114/kultura.v1i1.18266.

Effendi, R., \& Reinita, R. (2020). Peningkatan Hasil Belajar pada Pembelajaran Tematik Terpadu Menggunakan Model Cooperative Script di Kelas IV SD. Jurnal Pendidikan Tambusai, 4(3), 1814-1819. https://doi.org/10.31004/jptam.v4i3.640.

Fakhrurrazi, F. (2018). Hakikat Pembelajaran yang Efektif. At-Tafkir, 11(1), 85. https://doi.org/10.32505/at.v11i1.529.

Faradiba, F. (2020). Analisis Data Berkala. Universitas Kristen Indonesia.

Firman, Baedhowi, \& Murtini, W. (2018). The Effectiveness of The Scientific Approach to Improve Student Learning Outcomes. International Journal of Active Learning, 3(2), 86-91. https://doi.org/10.15294/ijal.v3i2.13003.

Fuadaturahmah. (2019). Pengaruh Model Pembelajaran Inkuiri dan Penggunaan Media Berbasis Komputer ( Cd Movie Dan Flash) terhadap Kreativitas Siswa MA Kelas XI pada Pokok Bahasan Koloid. Jurnal ANSIRU PAI, 2(2), 131-144. https://doi.org/10.30821/ansiru.v2i2.2033.

Hawkyard, R., Dempsey, I., \& Arthur-Kelly, M. (2014). The handwriting experiences of left-handed primary school students in a digital age: Australian data and critique. Australian Journal of Education, 58(2), 123-138. https://doi.org/10.1177/0004944114530062.

Helendra, \& Sar, D. R. (2021). Pengembangan Instrumen Asesmen Berbasis Literasi Sains Tentang Materi Keanekaragaman Hayati Kelas X. Journal for Lesson and Learning Studies, 4(1), 17-25. https://doi.org/10.23887/jlls.v4i1.34270.

Hutama, F. S. (2016). Pengembangan Bahan Ajar Ips Berbasis Nilai Budaya Using Untuk Siswa Sekolah Dasar. JPI (Jurnal Pendidikan Indonesia), 5(2), 113-124. https://doi.org/10.23887/jpi-undiksha.v5i2.8359.

Iriani, D. (2014). 101 Kesalahan Dalam Mendidik Anak (1st ed.). PT Elex Media Komputindo.

Iza, N., \& Anantyarta, P. (2018). Pengembangan Buku Ajar Perkembangan Hewan Berbasis Hasil Penelitian Regenerasi Sirip Kaudal Ikan Gatul (Poecilia sp.). Jurnal Pendidikan Biologi, 10(1), 1. https://doi.org/10.17977/um052v10i1p1-10.

Kholidin. (2017). Pengembangan Media Pembelajaran Menggunakan Program Video Scribe Sparkol Pada Mata 
Pelajaran Sejarah Kelas Xi Di Sekolah Menengah Atas. Jurnal Institusi, 06(12), 21. https://doi.org/10.36706/jc.v6i2.5319.

Krismawati, N. U. (2019). Pengembangan Bahan Ajar Penulisan Sejarah Berbasis Model Project-Based Learning. Indonesian Journal of Social Science Education (IJSSE), 1(2), 156-170. https://doi.org/10.29300/ijsse.v1i2.1905.

Kurnia, T. D., Lati, C., Fauziah, H., \& Trihanton, A. (2019). Model ADDIE Untuk Pengembangan Bahan Ajar Berbasis Kemampuan Pemecahan Masalah Berbantuan 3D. Seminar Nasional Pendidikan Matematika, 1(1), 516-525.

Kurniawan, A., \& Masjudin. (2017). Pengembangan Buku Ajar Microteaching Berbasis Praktik Untuk Meningkatkan Keterampilan Mengajar Calon Guru. Prosiding Seminar Nasional Pendidik Dan Pengembang Pendidikan Indonesia, 1(2), 28-36.

Mahardhika, P. S. (2020). Analisis Wacana Tangan Kidal Pada Grup Facebook Koki (Komunitas Orang Kidal Indonesia). $\quad$ Jurnal Commercium, $3(3), \quad 168-179$. https://ejournal.unesa.ac.id/index.php/Commercium/article/view/37973.

Mardianto, M., Syukri, M., \& Irwan S, I. (2021). Kebijakan Pendidikan Ramah Bertangan Kidal di Univeristas Islam Negeri Sumatera Utara Medan. Jurnal MUDARRISUNA: Media Kajian Pendidikan Agama Islam, 11(3), 363380. https://doi.org/10.22373/jm.v11i3.10367.

Muga, W., \& D.N.L., L. (2017). Pengembangan Bahan Ajar Elektronik Berbasis Model Problem Based Learning Dengan Menggunakan Model Dick And Carey. Journal of Education Technology, 1(4), 260-264. https://doi.org/10.23887/jet.v1i4.12863.

Mulyaningsih, I. (2015). Pemerolehan Bahasa Anak Pada Usia 4 Tahun dengan Whole Language. AWLADY: Jurnal Pendidikan Anak, 1(2), 1-13.

Nasution, H. F. (1377). Instrumen penelitian dan urgensinya dalam penelitian kualitatif. IAIN Padangsidimpuan, 1(1), 68-70. http://jurnal.iain-padangsidimpuan.ac.id/index.php/Al-masharif/article/view/721.

Nikmah, N. A., Rohman, F., \& Suhadi. (2019). Buku Ajar Ekologi Komunitas Flora Savana Bekol Taman Nasional Baluran Berbasis Problem Based Learning untuk Matakuliah Ekologi. Jurnal Pendidikan: Teori, Penelitian Dan Pengembangan, 4(12), 1655-1659. https://doi.org/10.17977/jptpp.v4i12.13085.

Novferma, Effendi, Z., \& Evtita. (2018). Pengembangan Buku Ajar Matematika Ekonomi Berbasis Problem Based Learning yang Mendukung Kemampuan HOTS Mahasiswa. Edumatica: Jurnal Pendidikan Matematika, 8(2), 45-54. https://doi.org/10.22437/edumatica.v8i2.5496.

Nurwulan, N. R., \& Kristiani, A. B. (2020). Potensi Kelainan Muskuloskeletal pada Siswa Kidal. Jurnal Kesehatan Masyarakat Indonesia, 15(2), 9. https://doi.org/10.26714/jkmi.15.2.2020.9-12

Oktaviana, D., Susiaty, U. D., Studi, P., \& Matematika, P. (2020). Pengembangan Bahan Ajar Matematika Diskrit dalam Meningkatkan Kemampuan Pemecahan Masalah Matematis Mahasiswa IKIP PGRI Pontianak. Jurnal SAP (Susunan Artikel Pendidikan), 4(3), 186-191. https://doi.org/10.30998/sap.v4i3.6280.

Palma, M. A., \& Andjarwati, A. L. (2016). Pengaruh Kualitas Produk, Kemudahan, Dan Harga Terhadap Niat Beli Ulang Dengan Kepuasan Sebagai Variabel Intervening (Studi Pada Pelanggan Produk Fashion Melalui Toko online di Surabaya). Jurnal Riset Ekonomi Dan Manajemen, $16(1), 84$. https://doi.org/10.17970/jrem.16.60106.id.

Prasetiyo, N. A., \& Perwiraningtyas, P. (2017). Pengembangan Buku Ajar berbasis Lingkungan Hidup pada Mata Kuliah Biologi di Universitas Tribhuwana Tunggadewi. Jurnal Pendidikan Biologi Indonesia, 3(1), 19. https://doi.org/10.22219/jpbi.v3i1.3969.

Pratama, F. D., \& Swasty, W. (2018). Logo dan Signage sebagai Identitas Visual (Studi Kasus: Stadion Gelora Bandung Lautan Api). ANDHARUPA: Jurnal Desain Komunikasi Visual \& Multimedia, 4(02), 119-129. https://doi.org/10.33633/andharupa.v4i02.1598.

Putrantana, A. B., Hariyanto, E., \& Saichudin, S. (2020). Uji Kelayakan Bahan Ajar Berbasis Multimedia Interaktif untuk Siswa Sekolah Dasar pada Materi PermainanTradisional. Jurnal Pendidikan: Teori, Penelitian, Dan Pengembangan, 5(6). https://doi.org/10.17977/jptpp.v5i6.13584.

Rahayu, R., \& Ismawati, R. (2019). Pembelajaran Berbasis Masalah Pada Materi Pencemaran Lingkungan Sebagai Upaya Melatih Kemampuan Pemecahan Masalah Pada Siswa Smk. Indonesian Journal of Natural Science Education (IJNSE), 2(2). https://doi.org/10.31002/nse.v2i2.706.

Rahayu, S., \& Hidayati, W. N. (2018). Meningkatkan Hasil Belajar Matematika Melalui Penggunaan Media Bangun Ruang Dan Bangun Datar Pada Siswa Kelas V Sdn Jomin Barat I Kecamatan Kotabaru Kabupaten Karawang. Jurnal Pendidikan Sekolah Dasar, 4(2), 204. https://doi.org/10.30870/jpsd.v4i2.3854.

Rahmadani. (2019). Metode Penerapan Model Pembelajaran Problem Based Learnig (Pbl). Lantanida Journal, 7(1), 75. https://doi.org/10.22373/lj.v7i1.4440.

Rezeqi, S., Brata, W. W. W., Handayani, D., \& Gani, A. R. F. (2020). Analisis Kebutuhan Bahan Ajar Taksonomi Organisme Tingkat Rendah Terhadap Capaian Pembelajaran Berbasis KKNI. Jurnal Pelita Pendidikan, 8(2), 174-180. https://doi.org/10.24114/jpp.v8i2.17697. 
Safitri, E. R., \& Nurkamilah, S. (2020). Pengembangan Bahan Ajar Digital Berbasis Android untuk Peserta Didik Berkebutuhan Khusus. Journal of Education and Instruction, 3(2), 296-304. https://doi.org/10.31539/joeai.v3i2.1612.

Saidah, N., Parmin, \& Dewi, N. R. (2014). Pengembangan LKS IPA Terpadu Berbasis Problem Based Learning Melalui Lesson Study Tema Ekosistem Dan Pelestarian Lingkungan. USEJ - Unnes Science Education Journal, 3(2). https://doi.org/10.15294/usej.v3i2.3357.

Salu, B., \& Tadius. (2018). Pengaruh Metode Pembelajaran Jelajah Alam Sekitar (JAS) Terhadap Motivasi Dan Hasil Belajar IPA Siswa Kelas VI SDN 1 Rantepao Keb. Toraja Utara. Jurnal KIP, 7(3), 36-53. https://doi.org/10.0901/jkip.v7i3.475.

Shofiyah, N., \& Wulandari, F. E. (2018). Model Problem Based Learning (PBL) dalam Melatih Scientific Reasoning Siswa. Jurnal Penelitian Pendidikan IPA, 3(1), 33. https://doi.org/10.26740/jppipa.v3n1.p33-38.

Soekisno, R. B. A. (2015). Pembelajaran Berbasis Masalah Untuk Meningkatkan Kemampuan Argumentasi Matematis Mahasiswa. Infinity Journal, 4(2), 120. https://doi.org/10.22460/infinity.v4i2.77.

Sudarma, I. K. (2015). Desain Pesan Kajian Analitis Desain Visual Teks dan Image. Graha Ilmu.

Sukardi. (2008). Metode Penelitian Pendidikan Kompetensi dan Praktiknya. Bumi Aksara.

Sukmaangara, B., Muhtadi, D., \& Madawistama, S. T. (2021). Bagaimana Siswa Menyelesaikan Soal Berpikir Kreatif Matematis Ditinjau Dari Dominasi Otak? Journal of Authentic Research on Mathematics Education (JARME), 3(2), 151-164. https://doi.org/10.37058/jarme.v3i2.3218.

Suplemen, P., Ajar, B., Berbasis, B., \& Identifikasi, R. (2017). Pengembangan Suplemen Bahan Ajar Biologi Berbasis Riset Identifikasi Bakteri untuk Siswa SMA. Journal of Innovative Science Education, 6(2), 155161. https://doi.org/10.15294/jise.v6i2.19713.

Tegeh, I. M., \& Sudatha, I. G. W. (2019). Model-Model Desain Pembelajaran. Universitas Pendidikan Ganesha.

Ulfaeni, S. (2018). Pengembangan Media Monergi (Monopoli Energi) Untuk Menumbuhkan Kemampuan Pemahaman Konsep Ipa Siswa Kelas Iii Sdn Pedurungan Kidul 02 Semarang. Profesi Pendidikan Dasar, 1(2), 143. https://doi.org/10.23917/ppd.v1i2.4990.

Ulfah, A., \& Jumaiyah, D. (2018). Pengembangan Bahan Ajar Mata Kuliah Bahasa Indonesia di Perguruan Tinggi Kabupaten Lamongan. Jurnal Inovasi Pendidikan, 2(1), 75-81.

Widiyanto, D. (2017). Penanaman Nilai Toleransi dan Keragaman Melalui Strategi Pembelajaran Tematik Storybook Pada Mata Pelajaran PPKn di Sekolah Dasar. Jurnal Pendidikan Kewarganegaraan, 7(2), 2836. https://doi.org/10.20527/kewarganegaraan.v7i2.4265. 